\title{
Physical Forcing Induced Coastal Vulnerability along the Gulf of Guinea
}

\author{
Angora Aman1 ${ }^{(0)}$, René A. Tano ${ }^{2 *}$, Elisée Toualy ${ }^{1}$, Foungnigué Silué1, Kwasi Appeaning Addo3, \\ Regina Folorunsho ${ }^{4}$
}

${ }^{1}$ Climate Tropical Team, Laboratory of Atmospheric Physics and Fluid Mechanics, Felix Houphouet Boigny University of Cocody, Abidjan, Cote d'Ivoire

${ }^{2}$ Laboratory of Fundamental and Applied Physics, Nangui Abrogoua University, Abidjan, Cote d'Ivoire

${ }^{3}$ Institute for Environment and Sanitation Studies, University of Ghana, Accra, Ghana

${ }^{4}$ Nigerian Institute for Oceanography and Marine Research, Lagos, Nigeria

Email: *tanorene@gmail.com, angora.aman@gmail.com

How to cite this paper: Aman, A., Tano, R.A., Toualy, E., Silué, F., Addo, K.A. and Folorunsho, R. (2019) Physical Forcing Induced Coastal Vulnerability along the Gulf of Guinea. Journal of Environmental Protection, 10, 1194-1211.

https://doi.org/10.4236/jep.2019.109071

Received: August 5, 2019

Accepted: September 14, 2019

Published: September 17, 2019

Copyright $\odot 2019$ by author(s) and Scientific Research Publishing Inc. This work is licensed under the Creative Commons Attribution International License (CC BY 4.0).

http://creativecommons.org/licenses/by/4.0/ Open Access

\begin{abstract}
Coastal areas of the Gulf of Guinea experience accelerated degradation as a result of erosion and flooding associated with intensification of extreme marine-meteorological phenomena. The coastal erosion process, especially on the sandy or muddy littoral, constitutes one of the main factors of the degradation of the Gulf of the Guinean coast. These risks, which are still poorly studied, could increase over the coming decades because of climate change and the human activities that exacerbate them. Data related to ocean forcing (tide, wave, and sea level anomaly), to hydrologic parameter (rainfall) and to the state (geomorphology, coastal slope, and rate of coastal retreat) of the coast were analyzed by several statistical methods and a numerical vulnerability model to map the vulnerability of the different coastlines of this region. The results showed that the vulnerability of these coastal areas is influenced by geomorphology, tide, waves and rainfall intensity. $24.34 \%$ and $37 \%$ of the entire coast are of low and moderate vulnerability respectively. While $26.98 \%$ and $11.66 \%$ are of high and very high vulnerability respectively. This information could facilitate developing sustainable policies to effectively manage hazards in this coastal zone.
\end{abstract}

\section{Keywords}

Mapping, Physical Forcing, Coastal Vulnerability Index, Gulf of Guinea

\section{Introduction}

The coastline is dynamic and is, therefore, an area of constant change. The changes 
depend on geology and geomorphology; the natural processes such as tidal, swell and wind sea waves exacerbated by sea-level rise [1] and annual rainfall change [2]. The changes of the coastline also depend largely on human activities such as urbanization, ports defense construction, removal of sand and vegetation and construction of barrage [3]. Changes often result in erosion and inundation of coastal areas or accretion of sediments.

Coastline changes induced by erosion and accretion are natural processes that take place over a range of time scales. They may occur in response to smaller-scale (short-term) events, such as storms, regular wave action, tides, and winds, or in response to large-scale (long-term) events such as sea levels (rise/fall) and coastal land subsidence or emergence [4] [5]. During certain periods of the year, long-shore current resulting from these processes transport coastal sediments in one direction that come back later. In fact, this transport is essential to keep coastlines in morphodynamic equilibrium. However, an imbalance between sediment supply and demand may lead to the erosion of coastal sections that were historically stable.

During these last decades, the rate of coastal retreat and permanent inundation which cause the destruction of infrastructures, ecosystem and losses of human life increases year by year. The occurrence and magnitude of these phenomena have increased along the Gulf of Guinea (GG) coastal area and could threaten more than $31 \%$ of the regional population [6] which live in coastal megacities (such as Abidjan, Accra, and Lagos), the main infrastructures and a diverse ecosystem that contribute to human well-being. The need for protection, mapping and monitoring becomes urgent due to the increasing population density, socio-economic activities, and the exposure of coastal infrastructure and ecosystem along this coastal area. The coastal dwellers, particularly, are severely impoverished due to environmental degradation and increasing population impact on environmental resources.

Several studies have been undertaken to evaluate the vulnerability of some sections of the GG coastal area. A regional study of coastline monitoring and development of a coastal master plan for West Africa was carried out in 2010 by West African Economic and Monetary Union (WAMU). The results of this study have identified coastal sections sensitive to coastal erosion [7]. Another study undertaken by WAMU [3] as a part of West African Coastal Observation Mission Project (WACOM) permitted the collection, processing, and diffusion of quality information to existing advisory and decision-making bodies [3]. The current West Africa Coastal Areas Management Program (WACA) project proposes to reduce the coastal erosion phenomenon through the construction of coastal protection works [8]. [9] has integrated coastal relief, subsidence, extensive, shoreline retreat, and high wave/tide energies into coastal vulnerability index defined by [10] to show that western part of Accra is highly vulnerable than the centre and the Eastern part. [2] has developed an index based on geomorphology, coastal elevation, geology, local subsidence, sea-level rise, shoreline change rates, mean tidal range, mean wave height and population density. This 
study identified about $50 \%$ of the $540 \mathrm{~km}$ shoreline of Ghana as being vulnerable.

The study carried out by [11], based on processes (relative sea-level rise, tidal range, and wave height) and state factors (geomorphology, coastal slope, and coastline change rate) showed that vulnerability of the Ivorian coastal section increases eastward and, depends strongly on geomorphology and swell wave energy coming from southern Atlantic. More recently, [1] defined an integrated index based on physical (geomorphology, coastal slope, coastal retreat rate, relative sea-level rise and wave/Tide energy) and socio-economic (coastal population density, harbor, airport, road, land use and protected area) factors. Results of this study revealed that vulnerability of the western and the eastern coastlines of Cote d'Ivoire are strongly influenced by human activities, while physical forcing significantly affects the vulnerability of the central section. But these works could be ineffective because no significant studies at regional scale integrating the same methodology approaches for coastal vulnerability analysis have been undertaken until now.

However, despite the fact that these studies have increased our knowledge of the vulnerability of a part of the GG coastal area, they seem limited. The use of different methods and variables cannot permit a comparison of the degree of vulnerability of these coastal sections of the entire GG. Moreover, heavy precipitation impact which affects sediment balance [2] through sedimentary inputs from terrestrial sources towards the beaches [3], hasn't been taken into account in different formulation to quantify the vulnerability index. As a matter of fact, numerous river systems drain the entire coast of the Guinea Current Large Marine Ecosystem (GCLME). The most important draining into GCLME coastal areas includes Niger (Nigeria), Volta River (Ghana), Comoe River (Cote d'Ivoire). These rivers enter the Atlantic ecosystem from an extensive network of catchment basins transporting great quantities of sediment (Table 1). During the 1970s and 1980s, river inputs decrease in the region coinciding with the period of sub-Saharan drought [12] that resulted in reduced flows of almost all the rivers [13]. Moreover, the majority of these rivers have been dammed mostly for energy and irrigation purposes, resulting in significant alteration of their hydrology and

Table 1. Sedimentological characteristics of rivers in some countries of the Gulf of Guinea (Adapted from [22]).

\begin{tabular}{cccccc}
\hline Country & Rivers & $\begin{array}{c}\text { Catchment } \\
1000 \mathrm{~km}^{2}\end{array}$ & $\begin{array}{c}\text { Sediment yield } \\
\mathrm{t} / \mathrm{km}^{2} / \text { year }\end{array}$ & $\begin{array}{c}\text { Sediment load } \\
1000 \mathrm{t} / \text { year }\end{array}$ & $\begin{array}{c}\text { Sand } \\
\text { Mi } \mathrm{m}^{3} / \text { year }\end{array}$ \\
\hline Cote d'Ivoire & $\begin{array}{c}\text { Sassandra, Comoe, } \\
\text { Cavally, Bandama }\end{array}$ & 340 & 65 & 22,100 & 2.13 \\
Ghana & Pra, Volta & 440 & 70 & 17,900 & 1.33 \\
Togo & Mono & 29 & 60 & 1600 & 0.18 \\
Benin & Oueme & 48 & 50 & 2400 & 0.23 \\
Nigeria & Ogun, Niger, Cross & 2263 & 80 & 48,600 & 3.3 \\
\hline
\end{tabular}


sediment flow, creating inevitable downstream impacts and accelerating coastal erosion processes. So, precipitations play a key role in the Gulf of Guinea ecosystem.

The aim of this study is to develop a new coastal vulnerability index for identifying and mapping the degree of vulnerability of the different coastal sections of the GG coastal area based on only one methodology approach integrating the precipitation factor. The paper is arranged as follows: material and methods are described in Section 2; results and discussion are reported in Section 3, with a conclusion in Section 4.

\section{Material and Methods}

\subsection{Material}

This subsection focuses on study area characteristics and data used description.

\subsubsection{Study Area}

The current study area ranges between Cote d'Ivoire and Nigeria (Figure 1). It includes other countries such as Ghana, Benin and Togo. This section of GG coast stretches over $2000 \mathrm{~km}$ and lies between $7^{\circ} 30 \mathrm{~W}$ and $9^{\circ} \mathrm{E}$ and around the $5^{\text {th }}$ parallel. All capitals of countries of this coastal section are situated in the coastal area which is classified as low-lying ( $\leq 10 \mathrm{~m})$ coastal area. According to [14], the geomorphology of this coastal area is generally composed of low cliffs and Sandy beaches washed by ocean waves. The Ivorian coast is constituted by rocky coast between Cap Palmas and Sassandra, Medium cliff between Sassandra and Abidjan, and from Abidjan to the Cape of Three Points, the coast is composed of sandy beaches [11]. Ghana's coast is also divided into western, central and eastern sections [2] [9] [15]. The Western coast (from the border with Cote d'Ivoire to Ankobra River) covers $90 \mathrm{~km}$ of coastline and is a low energy beach. It consists of flat and wide beaches backed by coastal lagoons. The Central coast represents a medium energy environment interspersed with embayed coasts, rocky headlands and sand bars or spits enclosing coastal lagoons. It consists of $310 \mathrm{~km}$ of shoreline extending from the west of Prampram to the estuary of Ankobra River near Axim. The Eastern coast stretches over $140 \mathrm{~km}$ from the border with the Republic of Togo to Prampram. It is a high-energy coast with wave heights often exceeding $1 \mathrm{~m}$ in the surf zone. The Togolese Coast is characterized by sandy and barrier beaches and is slightly above sea level $(0-5 \mathrm{~m})$ [16]. The length of this coast does not exceed $50 \mathrm{~km}$. Sandy beaches interrupted by lagoon characterized the geomorphology of the coastal area of Benin. The length of this coastal section is $125 \mathrm{~km}$. The Nigerian coastal area can be divided into four main geomorphic zones namely: Barrier Lagoon Coast (situated between Benin border and Benin river), the Mahin Mud Coast (from Benin river to Niger Delta), the Niger Delta comprised between the end of the Niger Delta and Imo River border and the Strand Coastline (from Imo River eastwards to the Cross River estuary along the Cameroon boundary). The coastal slopes are low ( $\leq 34 \%)$ along the entire coast of the Gulf of Guinea [11] [14] [17]. The type of ocean tide along the 


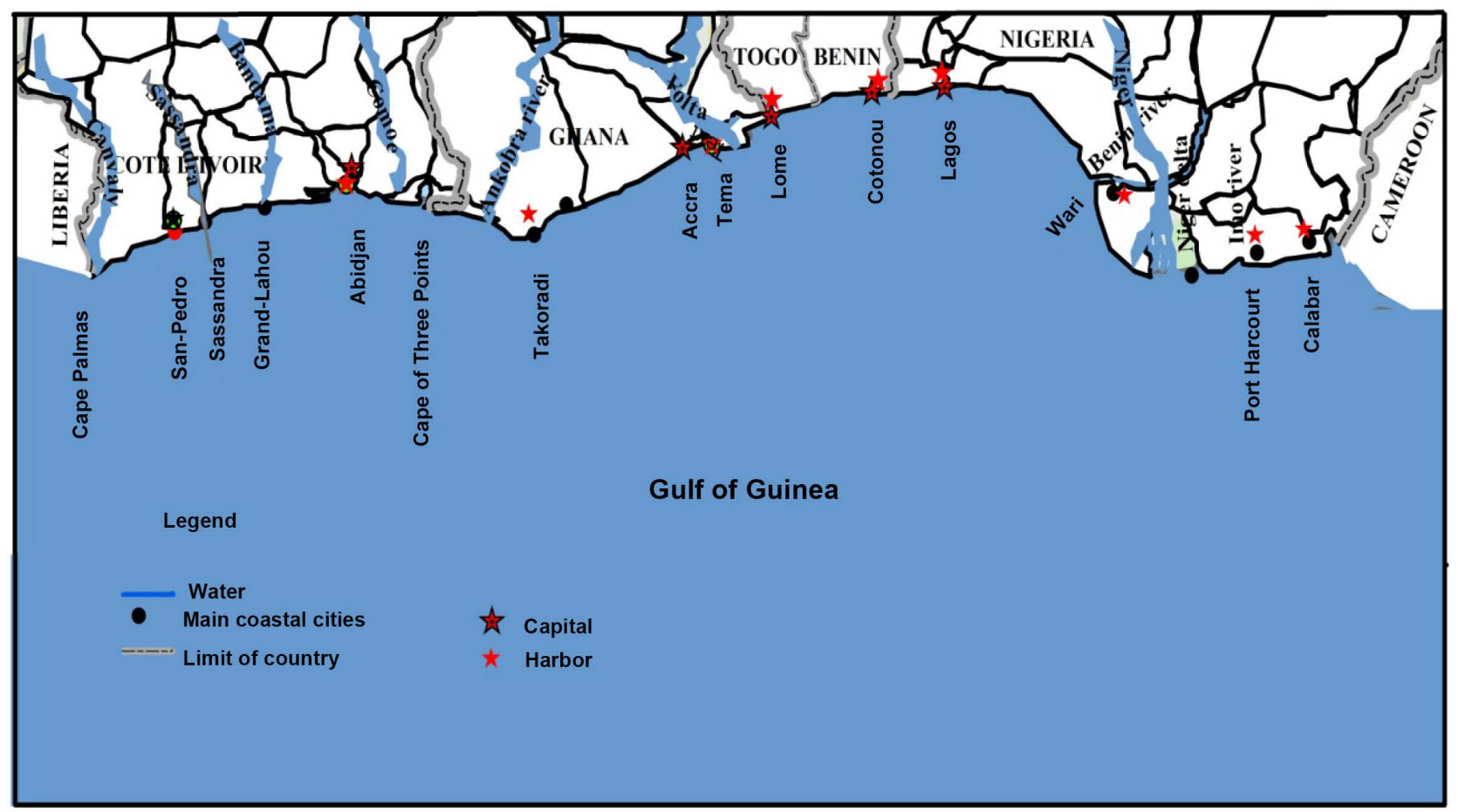

Figure 1. Location of the study area.

coast of Ghana, Togo and Benin is semi-diurnal and it is semi-diurnal with diurnal inequality along the Cote d'Ivoire and Nigeria coastline. The tidal range is ranged between 1 to $3 \mathrm{~m}$. the maximum tidal range is observed at Calabar. Intense tidal activities are more destructive along the Mahin mud coast during spring tides, during which tidal range reaches $1.5 \mathrm{~m}$. The coastal areas of GG are washed by two categories of wave. These are constituted by Wind Sea generated by local wind and swell wave coming from the southern ocean. Wind seas have a weak impact on coastal zone because local wind has weak speed compared to storm generated swells.

Most coastal hazards such as erosion and temporal or permanent inundations are induced by energetic waves coming from the southern ocean [1] [11] [18]. The height of these waves can reach over 3 to $4 \mathrm{~m}$ during the rainy months from June to September when storms are more frequent. In addition, the currents that transport sediments are composed of a longshore current induced by breaking energetic swell waves with a maximum speed of $0.8 \mathrm{~m} / \mathrm{s}$ [19], an energetic tidal current, and a weak Guinea current, with a maximum speed $(0.7 \mathrm{~m} / \mathrm{s})$, observed during the major upwelling season [20] [21]. The climate of this region is a subequatorial type. It consists of two alternating rainy and dry seasons. The rainy season lies between April to July. In this coastal area, economic activities are dominated by agriculture, fisheries, mineral extraction, and trades. The transportation activities are supported by the different harbors located in San Pedro and Abidjan (Cote d'Ivoire), Sekondi-Takoradi and Accra (Ghana), Lome (Togo), Cotonou (Benin) and Tin Can Island Port, Calabar Port, Delta Port, Rivers Port and Onne Port, Rivers Port, Port Harcourt, and Onne Port (Nigeria). The 
rapidly growing population increases urbanization and economic activities. The increase in socio-economic activities affects the state of the coastal environment and confirms environmental information to help protect property and save lives through the implementation of adequate adaptation strategies.

\subsubsection{Data}

The sources of the coastal data used in this study include articles, era-interim significant wave height reanalyse dataset provided by the European Centre for Medium-Range Weather Forecasts (ECMWF) from 1979 to 2013 and the all satellite mission sea level anomaly from 1993 to 2014 provided by Archiving, Validation and Interpretation of the Satellite Oceanographic (AVISO). Coastal geomorphology and slope characteristics and tidal range data are taken from [2] [11] [14]. Coastal retreat rate data, which characterize the risk level of coastal erosion, are taken from [6].

Significant wave height $(\mathrm{SWH})$ data are available at https://apps.ecmwf.int/datasets/data/interim-full-daily/levtype=sfc/ in a $0.5 \times 0.5$ horizontal grid. These data are available from 1979 to the present, with a 6-hr temporal resolution. The rate of sea-level rise was performed by using daily sea-level anomalies (SLA) in a $0.25 \times 0.25$ horizontal grid from Archiving, Validation and Interpretation of the Satellite Oceanographic (AVISO,

https://www.aviso.com) data for the 1993-2018 period. Data were spatially averaged in the different coastal sections of the study area to obtain a chronological series. This parameter is used to show how the rise in sea-level could amplify the effect of spring tidal and swell waves on the different section of the coastal area. Precipitation data have been extracted from

https://www.esrl.noaa.gov/psd/data/gridded/data.gpcc.html. These data are provided by the Global Precipitation Climatology Centre (GPCC) in a $1 \times 1$ horizontal grid and cover the period from 1901 to 2013.

\subsection{Methods}

Drastic changes observed along the coastal areas are due to the impacts of physical parameters such as sea-level rise, wave, ocean tide [23] and precipitation on these areas. The analysis of the spatial and temporal variability is useful for understanding how these parameters could threaten coastal communities, infrastructure, and ecosystems. This analysis has been undertaken using the linear regression method. The value of the slope of the linear relationship between a variable being considered and time shows the implication of these changing parameters observed along the coast.

\subsubsection{Rainfall Index Variability}

We proceeded to the calculation of the annual averages of the precipitation and the Nicholson index [24] for the hydroclimatic parameters analysis, in order to highlight the fluctuations of the rainfall regimes and its probable impact on each coastal section of the northern coast of GG. This index which calculated each year 
over the study period is expressed as follow:

$$
I_{i}=\frac{X_{i}-X}{\sigma}
$$

with:

$I_{i}$ : rainfall index;

$X_{i}$ : yearly $i$ height cumulative rainfall in $\mathrm{mm}$;

$X$ : mean height of total cumulative rainfall on study period in $\mathrm{mm}$;

$\sigma:$ standard deviation of total height rainfall during the study period.

According to this formula, normal precipitation is characterized by an equal fluctuation of the rainfall time series around the abscise axis. During the spell period, the annual mean value is below the annual of the total time series and rainy period is characterized by the annual mean up to the total annual mean.

\subsubsection{Trend and Break-Point Estimation}

One of several methods commonly used for time series study is the Mann-Kendall non-parametric test for randomness against trend [25] [26]. This method has been extensively used for characterizing the temporal behavior (increase or decrease) of the ocean [27] [28] and hydroclimatic parameters time series. The trend analysis in this study is carried out by fitting the following model to a time series $X_{t}$ :

$$
X_{t}=b \times t+a+c \times R_{t-1}+\varepsilon_{t}
$$

where $a$ and $b$ are regression parameters, and $R_{t}$ is a red noise process with lag-1 autocorrelation $\mathrm{c}$ and $\varepsilon_{t}$ denotes a white noise process.

This model was used to identify the statistically significant trends at a $5 \% \mathrm{lev}$ el, and the trend estimator is based on Kendall's rank correlation [29].

\subsubsection{Coastal Vulnerability Index}

The method commonly used for quantifying and mapping the vulnerability of any coastal area is the coastal vulnerability index developed by [10] and modified by several authors ([1] [2] [30]-[38]) in order to take account other parameters that influence coastal areas degradation. In this study, the method proposed by [30] has been adopted with some modifications which integrate the risk related to precipitation variable and annual maximum significant wave height. The degrees of vulnerability associated with the precipitation have been obtained using the $20^{\text {th }}$ percentile of the time series (Table 2).

The physical variables used in this study, have been transformed in new nondimensional variable ranged between 1 and 5 according to [10] [30]. The coastal vulnerability index of the different section of the study area is therefore computed through the formula:

$$
C V I=\sqrt{\frac{a_{1} \times a_{2} \times a_{3} \times a_{4} \times a_{5} \times a_{6} \times a_{7}}{7}},
$$

where $a_{1}=$ geomorphology, $a_{2}=$ coastal slope, $a_{3}=$ relative sea level change rate, $a_{4}=$ shoreline erosion/accretion rate, $a_{5}=$ mean tide range, $a_{6}$ $=$ maximum wave height, and $a_{7}=$ rainfall index. 
Table 2. Ranking of risk variable related to rainfall index.

\begin{tabular}{cccccc}
\hline \multirow{2}{*}{ Variable } & Very Low & Low & Moderate & High & Very High \\
\cline { 2 - 6 } & 1 & 2 & 3 & 4 & 5 \\
\hline $\begin{array}{c}\text { Annual } \\
\text { maximum }\end{array}$ & $>0.86$ & $0.14-0.86$ & $-0.30-0.14$ & $-0.81--0.30$ & $<-0.30$ \\
Rainfall index & & & & & \\
\hline
\end{tabular}

The different results obtained will be used to identify and map the degree of vulnerability of the different coastal section of the northern of GG coastal area using the $25^{\text {th }}$ method.

\section{Results and Discussion}

\subsection{Change in Sea-Level along the Coast}

Figure 2 illustrates the temporal variability of sea level along each coastal sections of the GG. A strong seasonal and inter-annual variability of sea level is observed along each coastal section of the study area. Weaker value of sea level is observed yearly between June and July month. These minimum values correspond to the establishment of the seasonal coastal upwelling along the northern coast of GG. The inter-annual variability is characterized by a linear increasing trend showing an increase in sea-level change along the entire coast of GG. The secular trend is $3 \mathrm{~mm} / \mathrm{yr}$ along the coastal area from Cote d'Ivoire to Nigeria. This result and those obtained by [11] [39] and [40], are close. This upward trend in sea-level along these coastal areas is a strong threat for coastal communities, ecosystem, infrastructures and coastal tourism through coastal erosion and temporal or permanent inundation induced by this natural forcing. These coastal risks could be amplified by another parameter such as ocean wave.

\subsection{Variability and Trend of Maximum Significant Wave Height}

Ocean wave is one of the main physical forcings that induces drastic change in coastal areas. Analysis of the variability and trend of this parameter, therein, are of great importance to the operation and safety of shipping, offshore industries, coastal tourism and dwellers. Figure 3 shows the results of performing trend analysis on the 1979-2014 time series of annual maximum SWH at each coastal section, separately. A strong inter-annual variability of maximum SWH is observed along each coastal section which could be linked to storm activities in this region [41]. The different trends obtained are $1 \mathrm{~cm} / \mathrm{yr}$ along the coastal area which lies between Cote d'Ivoire to Benin and, $1.4 \mathrm{~cm} / \mathrm{yr}$ for the Nigeria coastal area. These results are in agreement with those obtained by [42] in previous studies concerning this study area. Changes in annual maximum SWH are found to be most significant along the Nigerian coastal area. The increased wave energy that washed these coastal sections increases the risk of coastal erosion as already reported by [41] [43] and inundation of the coastal assets during summer [11]. 

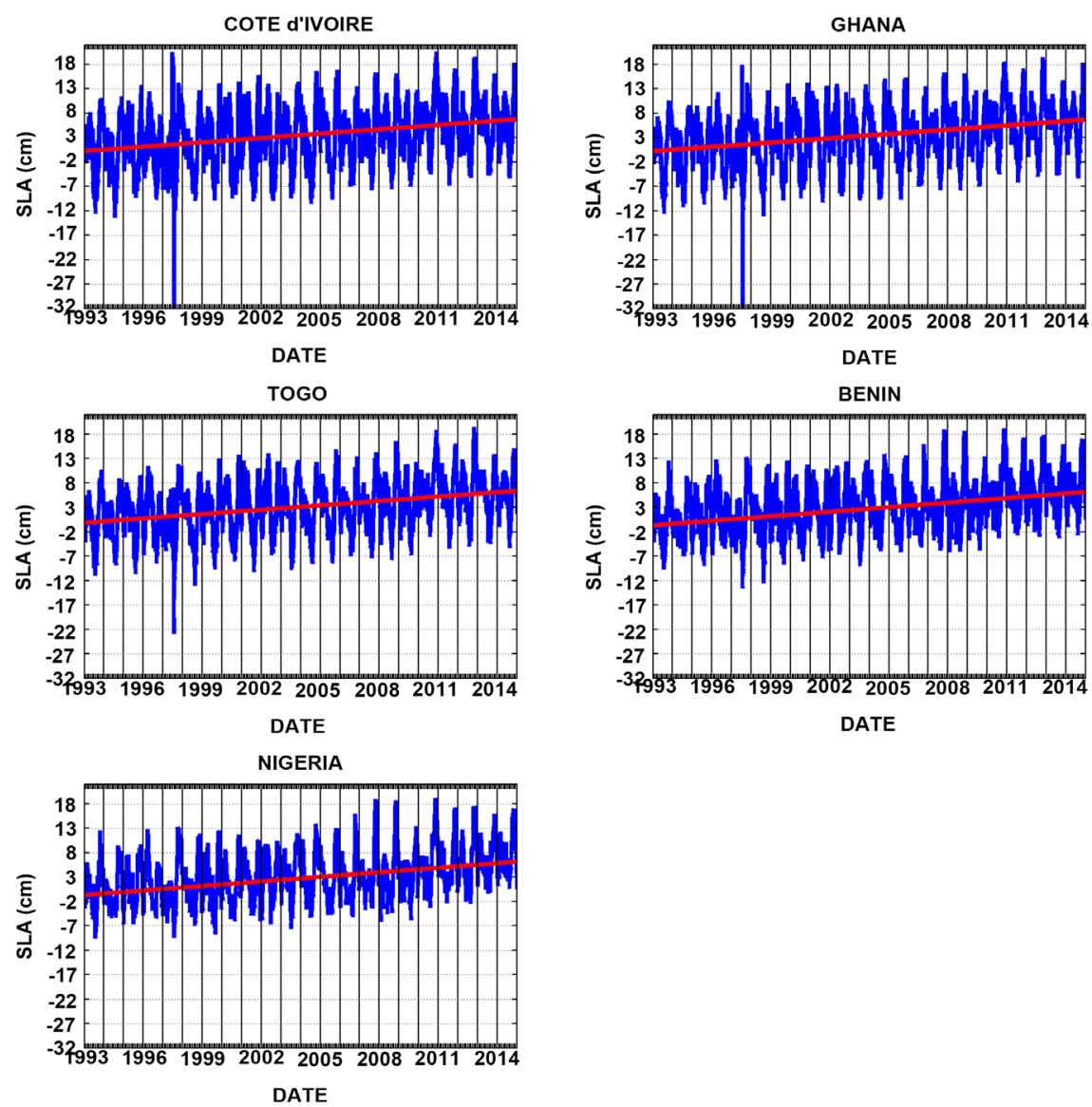

Figure 2. Variability and trend in sea-level anomaly (in $\mathrm{cm}$ ) along the northern coast of the Gulf of Guinea. The linear trend (in red) was added on each figure.

\subsection{Characteristic and Variability of the Rainfall Index}

\subsubsection{Characteristics of Rainfall Index along the Study Area}

Table 3 shows the statistic of the rainfall index time series obtained at the different coastal sections of the study area. This index performed over more than one hundred years (1901-2013) rainfall data is significant. The rainfall index value ranges between -8.04 (Togo) and 10.10 (Nigeria). The minimum value $(-5.84)$ of the mean index is observed at the Togolese coastal area while the maximum value (3.68) is observed at the Nigerian coastal area. The Togolese coastal area records weak precipitation than other coastal areas. That could induce a low sediment transport towards the beach and then exacerbate coastal erosion on this coastal section. In contrast, the Nigerian coast records the highest precipitation, hence the highest mean and maximum rainfall index. That suggests a strong sediment transport towards the beach and the attenuation of coastal erosion along this area.

\subsubsection{Rainfall Index Variability}

The rainfall variability analysis shows an alternation of humid, normal and dry periods in the precipitation regime characterized by breaks during different years and the coastal sections considered (Table 4). 

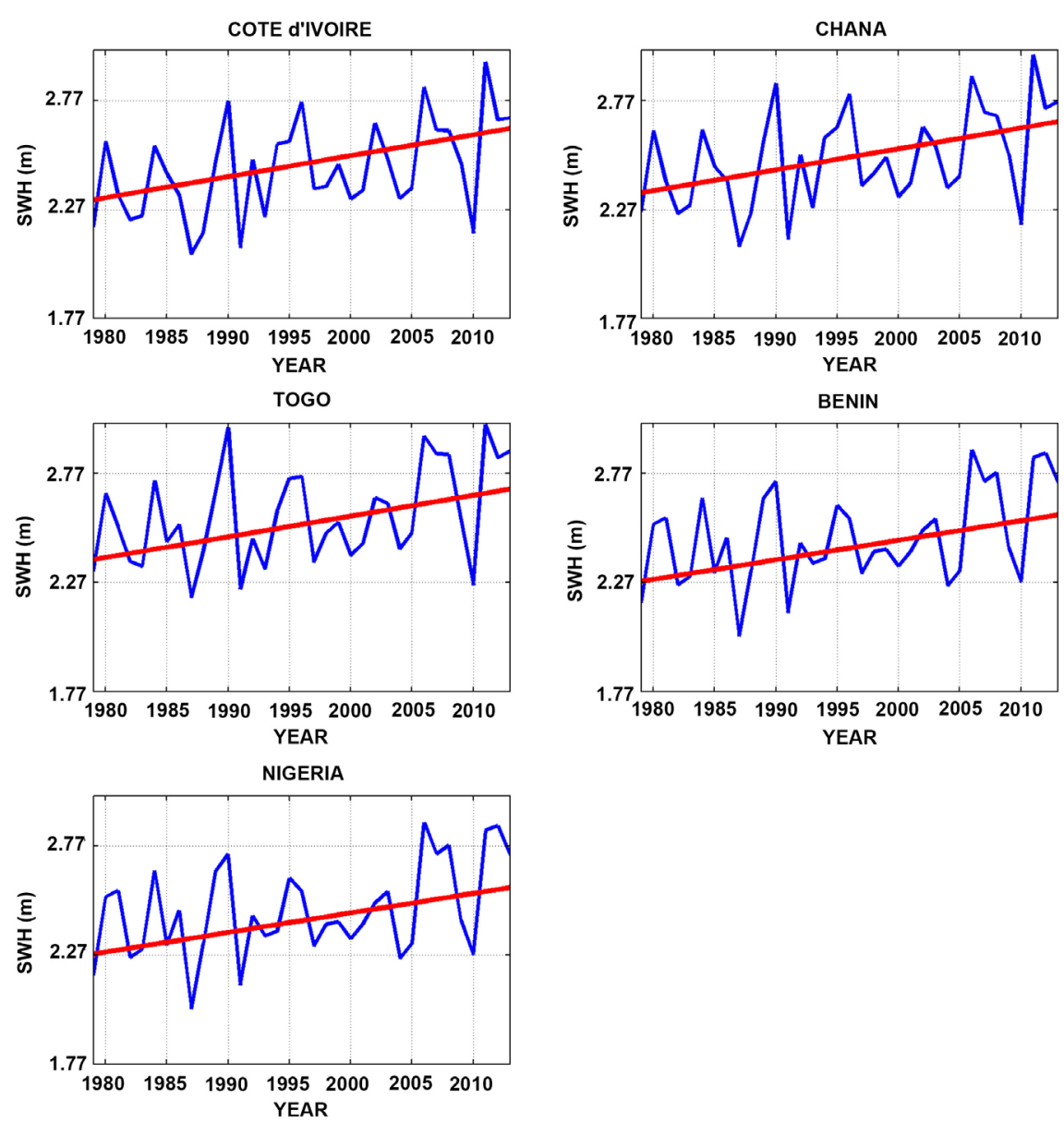

Figure 3. Variability and trend of the annual maximum wave height (in $\mathrm{m}$ ) along the northern coast of the Gulf of Guinea. The linear trend (in red) was added on each figure.

Table 3. Statistic of rainfall index along the study area.

\begin{tabular}{cccccc}
\hline Country & Cote d'Ivoire & Ghana & Togo & Benin & Nigeria \\
\hline Minimum & -3.25 & -5.56 & -8.04 & -6.00 & -0.14 \\
Maximum & 6.30 & 6.01 & -1.93 & 2.65 & 10.10 \\
Mean & 1.01 & -1.05 & -5.84 & --3.36 & 3.68 \\
\hline
\end{tabular}

Several changes according to Hubert segmentation statistical test have been detected and highlighted in each coastal section rainfall time series. The first breakpoints are observed in 1906, 1926, 1929 and 1913, 1923 at Nigeria and Cote d'Ivoire coastal areas respectively. Two breakpoints appear in 1940 (Ghana) and 1958 (Togo). The other breakpoints have been detected in 1968, 1971 and 1980 at Benin, Cote d'Ivoire and Togo, and Ghana coast respectively.

The temporal variability of rainfall exhibits dry and wet periods with unequal durations and intensities along each coastal section. An abundance of precipitation between 1901-1913 is illustrated by a linear positive increasing rainfall index with a slope of 59.33/yr along the Ivorian coast. This trend has been also observed along other coastal section such as that of Nigeria with a slope of 132/yr 
Table 4. Characterization of the temporal variability of rainfall index along each coastal section.

\begin{tabular}{cccc}
\hline Coastal area & Breakpoint & Period & Slope \\
\hline \multirow{3}{*}{ Cote d'Ivoire } & & $1901-1913$ & 59.3 \\
& & $1914-1923$ & -30.9 \\
& & $1924-1971$ & 1.79 \\
Ghana & $1923 ; 1971$ & $1972-2013$ & -3.4 \\
\hline \multirow{3}{*}{ Togo } & & $1901-1940$ & -0.5 \\
& & $1941-1980$ & -2.3 \\
& & $1981-2013$ & 3.2 \\
\hline \multirow{2}{*}{ Benin } & $1958 ; 1971$ & $1901-1958$ & 0.29 \\
& & $1959-1971$ & -14.8 \\
& & $1972-2013$ & 2.74 \\
\hline \multirow{2}{*}{1967} & $1901-1967$ & -0.15 \\
& & $1968-2013$ & 3.23 \\
\hline \multirow{2}{*}{ Nigeria } & $1901-1906$ & 132 \\
& & $1907-1926$ & -19.6 \\
& & $1927-1929$ & -294 \\
\hline
\end{tabular}

between 1901-1906. Some dry periods have succeeded wet periods or alternated with wet periods. The strongest decrease of rainfall with a slope of $-294 / \mathrm{yr}$ between 1927-1929, and -30.95/yr over the periods 1914-1923 have been recorded along Nigeria and Cote d'Ivoire coastal zone respectively. Some relative low decreases of precipitation have been observed along the coastal areas of Ghana, Togo and Benin (Table 3).

Figure 4 shows the long-term variability of the rainfall index associated with the different coastal section areas of GG from 1901 to 2013. Except the coastal area of Togo which records a positive linear trend with slope of $0.69 / \mathrm{yr}$, other long-term change exhibits a linear decrease with slopes $-2.12 / \mathrm{yr},-1.01 / \mathrm{yr}$, $-0.62 / \mathrm{yr}$, and $-0.70 / \mathrm{yr}$ over the period 1901-2013 along the Cote d'Ivoire, Ghana, Benin, and Nigeria coastal area respectively. All these results are in accordance with those of [44] and [45]. The non-linear repartition could be attributed to the latitudinal position of the ICZT, the intensity of the convection, the land use and land cover along the coast. This strong variability of the annual rainfall could be influenced by the drought which took place during 1968-1973 and 1982-1983 [46]. This in part is responsible of sediment deficit along the coastal area due to the reduction of the terrestrial sedimentary supply. Along this coastal area from Cote d'Ivoire to Nigeria, there is a strong influence of the pattern of river basin drainage. The most important include:

- Niger (Nigeria), drains an area of 1 million $\mathrm{km}^{2}$,

- Volta River (Ghana), with a drainage basin of $390,000 \mathrm{~km}^{2}$,

- Comoe River in Cote d'Ivoire. 

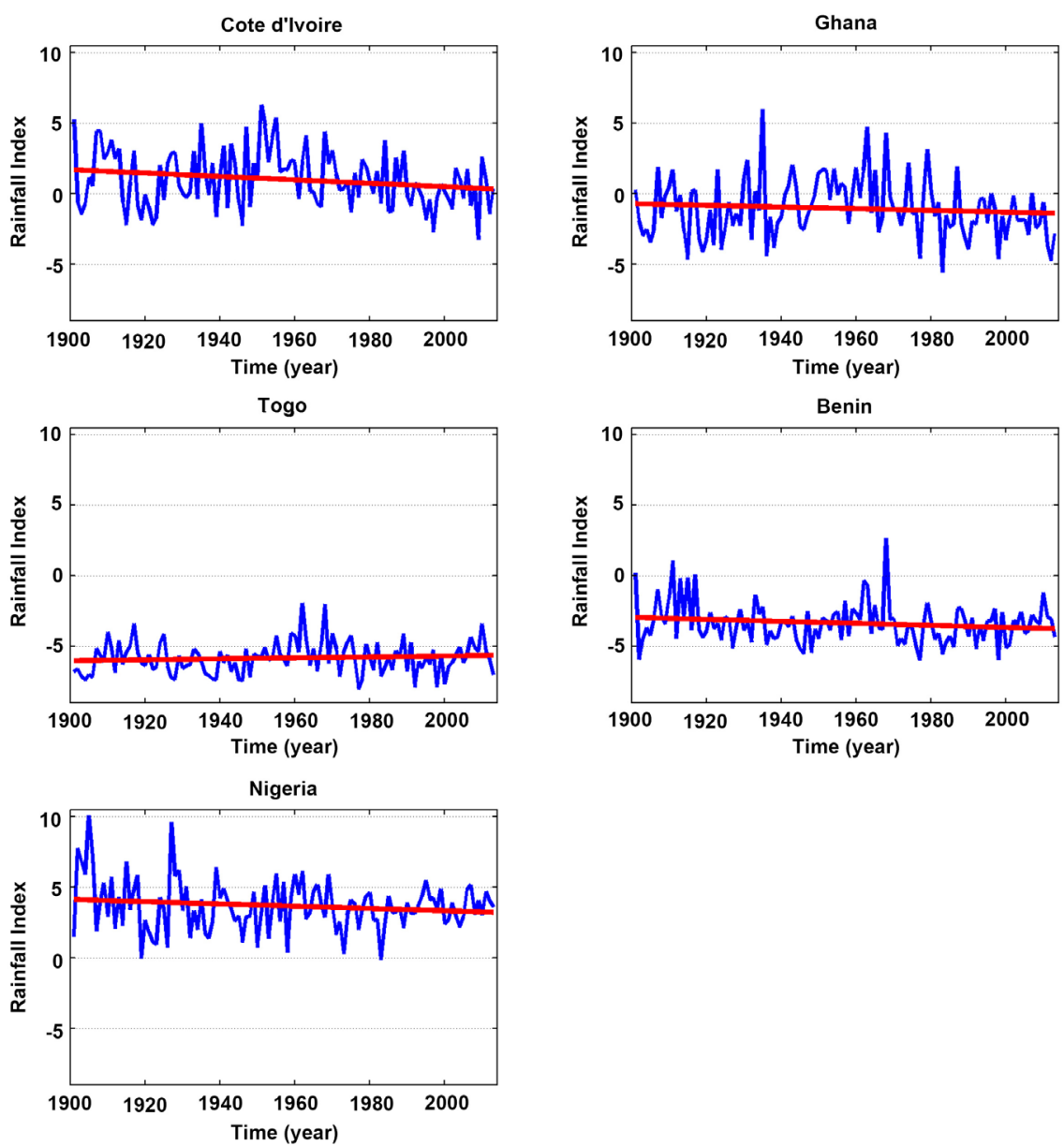

Figure 4. Variability and trend of rainfall index along the northern coast of the Gulf of Guinea. The linear trend (in red) was added on each figure.

There are also important sediments in the GCLME region provided by the Congo River, with the second-largest mean annual run-off and catchment area in the world, with a sediment discharge estimated at $30-80 \mathrm{tons} / \mathrm{km}^{2}$ and the Sanaga in Cameroon [22].

A full description of the Guinea Current circulation based on altimetry data is going on in order to understand the transport of the sediment along the northern coasts of the GG.

As mentioned above, these rivers play a key role in coastal vulnerability through sediment transport. The sediment transport contributes more than 92 million tones of sediment per annum into the Gulf of Guinea [47]. During the drought periods, there is a reduction in river flows which contribute to the deficit of sediments along the coastal area.

\subsection{Spatial Variability of the Coastal Vulnerability Index along the Northern of Gulf Guinea Coastal Area}

The coastal vulnerability index computed for the twelve coastal sections of GG ranged between 8.28 (Cape of Palmas-Sassandra) and 35.86 for the western part 
of Ghana, Togolese and Benin coastal areas. The $25^{\text {th }}, 50^{\text {th }}$ and $75^{\text {th }}$ percentiles are $17.89,22.64$ and 33.01 respectively. Low and moderate vulnerability coastal areas are characterized by indices lower than 17.89 and ranged between 17.89 and 22.64 respectively. High and very high vulnerability represented the CVI ranged between 22.64 and 33.01 and greater than 33.01 respectively. This result is in accordance with Table 1 . According to this table, the sand transported by the rivers of Ghana, Togo and Benin is the weakest in the study area. In the context of physical forcing, this last section appears to be more vulnerable than the other coastal areas. Retreat rates of up to $500 \mathrm{~m}$ have been recorded since the construction of the Lome (Togo) and Cotonou (Benin) ports. One of the most serious problems of the Togolese coast is that of coastal erosion. Over an area of approximately $35 \mathrm{~km}$, between the port and the protected sector, the coast retreats by approximately $10 \mathrm{~m}$ per year due to the sedimentary deficit caused by the port which blocks the sediment transit on its western side and causes the coastline to retreat in the Eastern part of the port of Lome [48].

Figure 5 exhibits the vulnerability level of each coastal section of the GG coastal areas. Low and moderate vulnerability characterize $24.34 \%$ and $37 \%$ of the total length of this coast respectively. These degrees of vulnerability concern the coastal sections between Cape of Palmas and Abidjan and, Prampram and Togo border. These results confirm those obtained by [2] [9] and [11]. The vulnerability of these coastal sections is controlled by geomorphology, rainfall index and tidal range as reported by [3].

$26.98 \%$ of this coastal area is characterized by a high degree of vulnerability due to physical parameters. The strong vulnerability of these sections is linked to

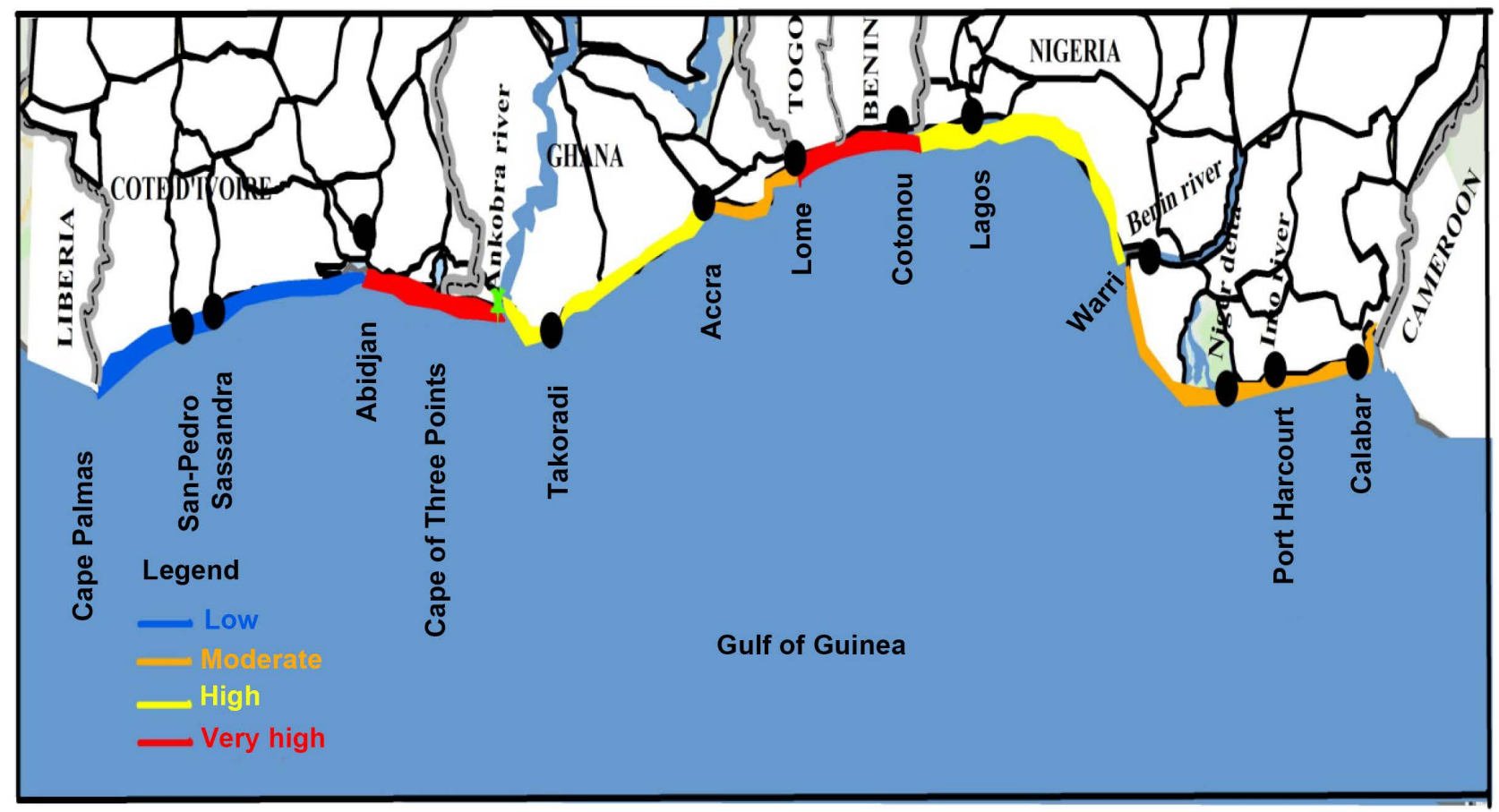

Figure 5. Vulnerability map of the Gulf of Guinea coastal areas sections. 
high-value risk of geomorphology, rainfall, tide energy and the rise in sea-level. This coastal area lies between Ankobra River to Prampram and Benin border to Benin River. [2] and [9] have classified the central coast of Ghana in the moderate risk category, but in this study, this coastal section falls in the high-risk category of vulnerability. The difference observed could be attributed to the rainfall index which has been taken into account in this study.

The coastal areas of Togo and Benin and those that lie between Cape Three Points and Ankobra River which represent $11.66 \%$ of the total length of the study area fall in the category of areas extremely vulnerable (very high) to physical forcing. The strong exposure of these coastal areas could be attributed to the decrease of the annual rainfall, the geomorphology characteristic and ocean tide energy that induce coastal erosion. This result confirms those obtained by previous authors ([1] [2] [3] [9] [11] [49] [50] [51]). These three coastal areas appear to be more vulnerable than the others part of GG coastal areas. These coastal sections will be continuously subjected to significant degradation linked to the natural and man-made causes. They require more attention for the preservation of infrastructure, coastal ecosystem and human life.

\section{Conclusions}

Coastal degradation constitutes a serious problem in many countries bordering the GG. This coastal area is highly subjected to natural erosion and sedimentation processes due to high wave energy, sea-level rise, precipitations as well as other extreme episodes of inter-annual variability of their occurrences. Human activities further exacerbate this inherent natural variability.

This study was interested in the mapping of the vulnerability of the different sections of the coastal zone of the northern coast of the GG using physical forcing such as geomorphology, coastal slope, rate of coastal retreat, relative sea-level rise, tidal range, maximum wave height and rainfall index.

The analysis of meteorology and ocean processes based on several statistical methods showed a decrease of the annual rainfall index and an increase of the sea level and annual maximum wave height. The decreasing of annual rainfall modifies sediment budget and causes coastal retreat in certain areas. The changing of climatic and ocean parameters intensifies stress level on coastal assets and increases its vulnerability. These natural alterations of the coastal areas could be exacerbated by the disturbance of the hydrological cycles and river damming.

The vulnerability of coastal sections of the study area depends on geomorphology, wave energy, sea-level rise, and rainfall intensity. The western and central part of Ghana's coast, the coastal areas of Togo and Benin, and the western part of Nigeria's coast, which represent $40 \%$ of the coastal areas of the northern coast of GG, are the most vulnerable to climate change and its associated factors. These results show the rating sections that require urgent intervention to reduce their vulnerability. They also show the low-risk areas where investors could implement their businesses. Results obtained in this study could be improved by introducing 
ocean pollution and costal current datasets in the computation of vulnerability index.

\section{Acknowledgements}

The authors thank the Global Precipitation Climatology Centre, the European Centre for Medium-Range Weather Forecasts (ECMWF) reanalysis, and the Archiving, Validation and Interpretation of Satellite Oceanographic Data (AVISO), which provided us with high-quality data.

\section{Conflicts of Interest}

The authors declare no conflicts of interest regarding the publication of this paper.

\section{References}

[1] Tano, R.A., Aman, A., Toualy, E., Kouadio, Y.K., Francois-Xavier, B.B.D. and Addo, K.A. (2018) Development of an Integrated Coastal Vulnerability Index for the Ivorian Coast in West Africa. Journal of Environmental Protection, 9, 1171-1184. https://doi.org/10.4236/jep.2018.911073

[2] Boateng, I., Wiafe, G., and Jayson-Quashigah, P.-N. (2016) Mapping Vulnerability and Risk of Ghana's Coastline to Sea Level Rise. Marine Geodesy, 40, 23-39. https://doi.org/10.1080/01490419.2016.1261745

[3] WACOM (West African Coastal Observation Mission) (2011) Regional Study for Shoreline Monitoring and Drawing up a Management Scheme for the West African Coastal Area. http://www.climateandcoast.com/moloa

[4] Prasetya, G.S. (2007) The Role of Coastal Forest and Trees in Combating Coastal Erosion. In: Braatz, S., Fortuna, S., Broadhead, J. and Leslie, R., Eds., Coastal Protection in the Aftermath of the Indian Ocean Tsunami: What Role for Forests and Trees, FAO, Bangkok, $25 \mathrm{P}$.

[5] Gracia, F.J., Anfuso, G., Benavente, J., Del Río, L., Domínguez, L. and Martínez, J.A. (2005) Monitoring Coastal Erosion at Different Temporal Scales on Sandy Beaches: Application to the Spanish Gulf of Cadiz Coast. Journal of Coastal Research, Special Issue 49, 22-27.

[6] WAMU (West African Economic and Monetary Union) (2010) West African Coastline Survey and Coastal Master Plan. 137. https://portals.iucn.org/library/sites/library/files/documents/2011-127-Ch2.pdf

[7] WACA (West Africa Coastal Areas Management Program) (2016) A Partnership for Saving West Africa's Coastal Areas. World Bank Group. http://pubdocs.worldbank.org/en/622041448394069174/1606426-WACA-Brochure.pdf

[8] Giardino, A., Schrijvershof, R., Nederhoff, C.M., Vroeg, H.D., Brière, C., Tonnon, P.-K., Caires, S., Walstraa, D.J., Sosa, J., van Verseveld, W., Schellekens, J. and Sloff, C.J. (2018) A Quantitative Assessment of Human Interventions and Climate Change on the West African Sediment Budget. Ocean and Coastal Management, 156, 249-265. https://doi.org/10.1016/j.ocecoaman.2017.11.008

[9] Appeaning Addo, K. (2013) Assessing Coastal Vulnerability Index to Climate Change: The Case of Accra-Ghana. Journal of Coastal Research, Special Issue 65, 1892-1897. https://doi.org/10.2112/SI65-320.1 
[10] Gornitz, V., White, T.W. and Cushman, R.M. (1991) Vulnerability of the US to Future Sea-Level Rise. In: Magoon, O.T., Ed., Proceedings of the Coastal Zone 91 Proceedings of the 7 th Symposium on Coastal \& Ocean Management, ASCE, Oak Ridge, 1345-1359.

[11] Tano, R.A., Aman, A., Kouadio, K.Y., Toualy, E., Ali, K.E. and Assamoi, P. (2016) Assessment of the Ivorian Coastal Vulnerability. Journal of Coastal Research, 32, 1495 1503. https://doi.org/10.2112/JCOASTRES-D-15-00228.1

[12] Lamb, P. (1982) Persistance of Subsaharan Drought. Nature, 299, 46-47. https://doi.org/10.1038/299046a0

[13] Mahé, C., Dessouassi, R., Cissoko, B. and Olivry, J.-C. (1998) Comparison of Interannual Fluctuations of Piezometry, Precipitation and Flow over the Bani-Douna Watershed. In: Servat, E., Hugues, D., Fritsch, J.M. and Hulme, M., Eds., Water Ressources Variability in Africa during the 20 th Century, Proceedings de la conférence Abidjan 98, ORSTOM/AlSH/UNESCO, Pub. AlSH No. 252, 289-295.

[14] Ibe, A.C. and Quelennec, R.E. (1989) Coastal Erosion Inventory and Control Methodology in the West and Central Africa Region. Regional Seas Reports and Studies, UNEP, Nairobi, 107 p.

[15] Appeaning Addo, K. (2015) Vulnerability of Ghana's Accra Coast to Sea Level Rise. Understanding Risk and Resilience in Complex Coastal Systems, 2nd Annual SURA Coastal Resilience Workshop, Fort Lauderdale, 26-28 October 2015, 15 p. http://scholarworks.uno.edu/resilience

[16] Blivi, A. (1993) Morphology and Current Dynamics of the Coast of Togo. Geo-EcoTrop, 17, 25-39.

[17] Houekpoheha, M.A., Kounouhewa, B.B., Hounsou, J.T., Tokpohozin, B.N. and Awanou, C.N. (2015) Statistical Analysis of Wave Heights on the Coast of Benin in the Gulf of Guinea: Energy Power of Non-Linear Swell in the Shoaling Zone. Revue des Energies Renouvelables, 18, 89-103.

[18] Toualy, E., Aman, A., Koffi, P., Marin, F. and Wango, T.E. (2015) Ocean Swell Variability along the Northern Coast of the Gulf of Guinea. African Journal of Marine Science, 37, 353-361. https://doi.org/10.2989/1814232X.2015.1074940

[19] Degbe, C.G.E., Sohou, Z., Oyede, L.M., Adje, C., Du Penhoat, Y., Bourles, B., Chuchla, R. and Almar, R. (2017) Evolution of the Coastline of the Beninese Coast from 2011 to 2014. CAMES Journal, 5, 21-28.

[20] Lemasson, L. and Rebert, J.-P. (1973) The Sea Currents in the Ivorian Gulf. Série Océanographie, 11, 67-95. https://doi.org/10.3406/camed.1973.1784

[21] Morlière, A. and Rebert, J.P. (1972) Hydrological Study of the Ivorian Continental Shelf. Volume III, No. 2, Centre Rech. Océano, csUt, Abidjan, 1-30.

[22] GCLME (Guinea Current Large Marine Ecosystem) (2006) Transboundary Diagnostic Analysis. 193 p. https://iwlearn.net/resolveuid/6f1a2c299933a974caa13da0aea62895

[23] Gornitz, V., Couch, S. and Hartig, E.K. (2002) Impacts of Sea Level Rise in the New York City Metropolitan Area. Global and Planetary Changes, 32, 61-88. https://doi.org/10.1016/S0921-8181(01)00150-3

[24] Nicholson, S.E., Kim, J. and Hoopingarner, J. (1988) Atlas of African Rainfall and Its Interannual Variability. Department of Meteorology, Florida State University, Tallahassee, $237 \mathrm{p}$.

[25] Mann, H.B. (1945) Non-Parametric Tests against Trend. Econometrica, 13, 245-259. https://doi.org/10.2307/1907187 
[26] Kendall, M.G. (1955) Rank Correlation Methods. Charles Griffin, 196 p.

[27] Wang, X.L. and Swail, V.R. (2001) Changes of Extreme Wave Heights in Northern Hemisphere Oceans and Related Atmospheric Circulation Regimes. Journal of Climate, 14, 2204-2221. https://doi.org/10.1175/1520-0442(2001)014<2204:COEWHI>2.0.CO;2

[28] Wang, X.L. and. Swail, V.R. (2002) Trends of Atlantic Wave Extremes as Simulated in a 40-Year Wave Hindcast Using Kinematically Reanalyzed Wind Fields. https://doi.org/10.1175/1520-0442(2002)015<1020:TOAWEA>2.0.CO;2

[29] Sen, P.K. (1968) Estimates of the Regression Coefficient Based on Kendall's Tau. Journal of the American Statistical Association, 63, 1379-1389. https://doi.org/10.1080/01621459.1968.10480934

[30] Thieler, E.R. and Hammar-Klose, E.S. (2000) National Assessment of Coastal Vulnerability to Sea-Level Rise: Preliminary Results for the U.S. Gulf of Mexico Coast. U.S. Geological Survey, Woods Hole, Open-File Report 00-179. https://doi.org/10.3133/ofr00179

[31] McLaughlin, S., McKenna, J. and Cooper, J.A.G. (2002) Socio-Economic Data in Coastal Vulnerability Indices: Constraints and Opportunities. Journal of Coastal Research, Special Issue No. 36, 487-497. https://doi.org/10.2112/1551-5036-36.sp1.487

[32] Wu, S.Y., Yarnal, B. and Fischer, A. (2002) Vulnerability of Coastal Communities to Sea-Level Rise: A Case Study of Cape May County, New Jersey, USA. Climate Research, 22, 255-270. https://doi.org/10.3354/cr022255

[33] Cutter, S.L., Boruff, B.J. and Shirley, W.L. (2003) Social Vulnerability to Environmental Hazards. Social Science Quarterly, 84, 242-261. https://doi.org/10.1111/1540-6237.8402002

[34] Chakraborty, J., Tobin, G.A. and Montz, B.E. (2005) Population Evacuation: Assessing Spatial Variability in Geophysical Risk and Social Vulnerability to Natural Hazards. Natural Hazards Review, 6, 23-33. https://doi.org/10.1061/(ASCE)1527-6988(2005)6:1(23)

[35] Li, K. and Li, G.S. (2011) Vulnerability Assessment of Storm Surges in the Coastal Area of Guangdong Province. Natural Hazards and Earth System Sciences, 11, 2003-2010. https://doi.org/10.5194/nhess-11-2003-2011

[36] Balica, S.F., Wright, N.G. and van Der Meulen, F. (2012) A Flood Vulnerability Index for Coastal Cities and Its Use in Assessing Climate Change Impacts. Natural Hazards, 64, 73-105. https://doi.org/10.1007/s11069-012-0234-1

[37] Karymbalis, E., Chalkias, C., Chalkias, G., Gigoropoulou, E., Manthos, G. and Ferentinou, M. (2012) Assessment of the Sensitivity of the Southern Coast of the Gulf of Corinth (Peloponnese, Greece) to Sea-Level Rise. Central European Journal of Geosciences, 4, 561-577. https://doi.org/10.2478/s13533-012-0101-3

[38] Boruff, B.J., Emrich, C. and Cutter, S.L. (2015) Erosion Hazard Vulnerability of US Coastal Counties. Journal of Coastal Research, 21, 932-942. https://doi.org/10.2112/04-0172.1

[39] Woodworth, P.L., Foden, P., Pugh, J., Mathews, A., Aarup, T., Aman, A., Nkebi, E., Odametey, J., Facey, R., Abdulgafor, M.Y.E. and Ashrar, M. (2009) Insight into Long Term Sea Level Change Based on New Tide Gauge Installations at Takoradi, Aden and Karachi. International Hydrographic Review, 1, 18-22.

[40] Evadzi, P.I.K. (2017) Regional Sea-Level at the Retreating Coast of Ghana under a Changing Climate. PhD. Dissertation, Universität Hamburg, Hamburg. 
[41] Ondoa, G.A., Bonou, F., Tomety, F.S., du Penhoat, Y., Perret, C., Degbe, C.G.E. and Almar, R. (2017) Beach Response to Wave Forcing from Event to Inter-Annual Time Scales at Grand Popo, Benin (Gulf of Guinea). Water, 9, 447. https://doi.org/10.3390/w9060447

[42] Osinowo, A.A., Okogbue, E.C., Eresanya, E.O. and Akande, O.S. (2018) Extreme Significant Wave Height Climate in the Gulf of Guinea. African Journal of Marine Science, 40, 407-421. https://doi.org/10.2989/1814232X.2018.1542343

[43] Almar Kestenare, E., Reyns, J., Jouanno, J., Anthony, E.J., Laibi, R., Hemer, M., Du Penhoat, Y. and Ranasinghe, R. (2015) Response of the Bight of Benin (Gulf of Guinea, West Africa) Coastline to Anthropogenic and Natural Forcing, Part 1: Wave Climate Variability and Impacts on the Longshore Sediment, R., Transport. Continental Shelf Research, 110, 48-59. https://doi.org/10.1016/j.csr.2015.09.020

[44] Hubert, P. and Carbonnel, J.P. (1989) Segmentation of the Hydrometric Series. Application to Rainfall and Flow Series of West Africa. Journal of Hydrology, 110, 349-367. https://doi.org/10.1016/0022-1694(89)90197-2

[45] Alamou, E., Gandomè, A., Quenum, M.L.D., Lawin, E.A., Badou, D.F. and Afouda, A.A. (2016) Spatio-Temporal Variability of Rainfall in the Ouémé Basin, Bénin. Afrique Science, 12, 315-328. http://www.afriquescience.info

[46] Ochou, A.D., Angora Aman, A., Kouadio, Y.K. and Assamoi, P. (2005) New Climate Zoning Based on Rainfall Variability in Cote d'Ivoire and Ghana. Revue de Géographie Tropicale et d environnement, 5, 34-46.

[47] Anani, L.S-A. (2013) Population Mobility in the Fluvio-Lagoon Complex of the Lower Ouémé Valley in Benin, West Africa. PhD Thesis, University of Abomey Calavi, Cotonou, $356 \mathrm{p}$.

[48] Folorunsho, R., Awosika, L.F. and Dublin-Green, C.O. (1998) An Assessment of River Inputs into the Gulf of Guinea. In: Ibe, A.C., Awosika, L.F. and Aka, K., Eds., Nearshore Dynamics and Sedimentology of the Gulf of Guinea, IOC/UNIDO, CEDA Press, Cotonou, 163-172.

[49] UNEP (1999) Regional Overview of Land-Based Sources and Activities Affecting the Coastal and Associated Freshwater Environment in the West and Central African Region. UNEP/GPA Co-Ordination Office \& West and Central Africa Action Plan, Regional Co-Ordinating Unit, $110 \mathrm{p}$. https://www.oceandocs.org/bitstream/handle/1834/312/UNEP171.pdf?sequence=1 \&isAllowed $=\mathrm{y}$

[50] Adegoke, J.O. and Ologunorisa, T.E. (2010) An Assessment of Recent Changes in the Niger Delta Coastline Using Satellite Imagery. Journal of Sustainable Development, 3, 277-296. http://www.ccsenet.org/journal/index.php/jsd/article/view/8558 https://doi.org/10.5539/jsd.v3n4p277

[51] Appeaning Addo, K. (2015) Monitoring Sea Level Rise-Induced Hazards along the Coast of Accra in Ghana. Natural Hazards, 78, 1293-1307.

https://doi.org/10.1007/s11069-015-1771-1 